\title{
Fifty to 100 times the size!
}

\section{FRÉDÉRIC H.T. ALLAIN}

Institute of Molecular Biology and Biophysics, ETH Zurich, CH-8093 Zürich, Switzerland

In recollecting on discoveries in the RNA field over the last 20 years, one can find of course many, considering the phenomenal field we are all working in. But of course as a structural biologist, I remember vividly the day I saw for the first time a talk presenting the high resolution structure of the bacterial $50 S$ ribosomal particle. If I do recollect well, the 10-minute talk was presented by Poul Nissen (from Tom Steitz's group in Yale) as the opening talk of the 2000 RNA Society meeting in Madison. I was just stunned and felt almost oppressed by what was shown in front of my eyes. The structure of this 1.5 megadalton protein-RNA complex containing 1500 nucleotides solved at $2.4 \AA$, was 16 times larger than the largest RNA solved to date (the P4-P6 group I intron from the Doudna lab) and more than 50 times larger than the proteinRNA complex I was personally working on at this time (Nucleolin tandem RRMs bound to RNA that I did as a postdoc in the Feigon lab). Suddenly, I and probably many others present in the auditorium were of course in awe of such an accomplishment and of the beauty of this large particle, and at the same time probably felt insignificant when comparing this achievement with our own. This compares with the participants of the $100 \mathrm{~m}$ dash at the 2008 Olympic games in Beijing who were running behind Usain Bolt and saw him winning with such a margin that today probably nobody remembers who finished second with the silver medal. I still remember how silent the Madison auditorium was at the end of the presentation and I am sure that few remember what was presented afterwards in this session. This was so astonishing. I gave a talk on the nucleolin structure in the same session but fortunately after the coffee break. I am not sure that I would have been able to give this talk if I had been in the first half! Of course, later people only talked about the ribosome structure during the meeting and several structural biologists and ribosome experts thought that they were now "out of business." In reality, this structure together with the one of the $30 \mathrm{~S}$ ribosome particle by the Ramakrishnan and Yonath labs revitalized the ribosome field, a field still today very active and competitive as evidenced by the numerous structures of bacterial, eukaryotic, and mitochondrial ribosomes that were published at high resolution by the labs of Noller, Cate, Ban, and the three labs mentioned earlier that shared the Nobel prize for chemistry in 2009.

This was 15 years ago and most of us are fortunately not "out of business." The ribosome in the end is probably the exception rather than the norm and solving the structure of an RNP still remains a challenging project for NMR, crystallography, or electron microscopy even if the complex is 100 times smaller than the bacterial 50S particle or the eukaryotic ribosome. The structural biology questions ahead of us in the RNP field do not concern necessarily large particles but rather for example how RNPs forming on messenger RNA dynamically change at the different stages of the life of an mRNA. To understand this, small RNA binding domains and their attached disordered tails and medium size RNPs like the UsnRNPs will still need to be characterized structurally. Moreover, we will need to know exactly where and when they bind and dissociate from the mRNA. We are still not there yet although nobody knows if a new revolution similar to the one we saw in 2000 is not waiting to blow our minds again.
Corresponding author: allain@mol.biol.ethz.ch

Article and publication date are at http://www.rnajournal.org/cgi/doi/ 10.1261/rna.051060.115. Freely available online through the RNA Open Access option.
(C) 2015 Allain This article, published in $R N A$, is available under a Creative Commons License (Attribution-NonCommercial 4.0 International), as described at http://creativecommons.org/licenses/by-nc/4.0/. 

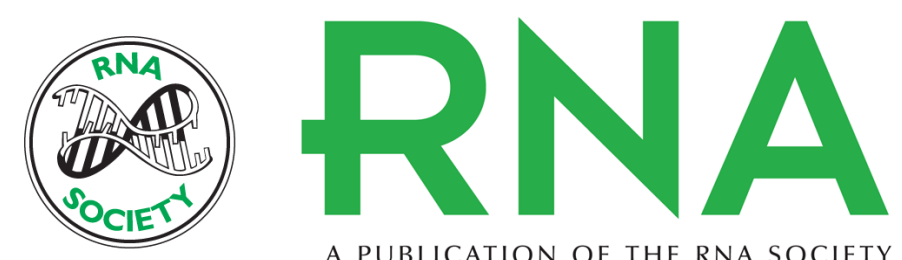

A PUBLICATION OF THE RNA SOCIETY

\title{
Fifty to 100 times the size!
}

\author{
Frédéric H.T. Allain
}

RNA $201521: 557$

Open Access Freely available online through the RNA Open Access option.

Creative This article, published in $R N A$, is available under a Creative Commons License Commons (Attribution-NonCommercial 4.0 International), as described at

License http://creativecommons.org/licenses/by-nc/4.0/.

Email Alerting Receive free email alerts when new articles cite this article - sign up in the box at the Service top right corner of the article or click here.

To subscribe to $R N A$ go to:

http://rnajournal.cshlp.org/subscriptions

(C) 2015 Allain; Published by Cold Spring Harbor Laboratory Press for the RNA Society 